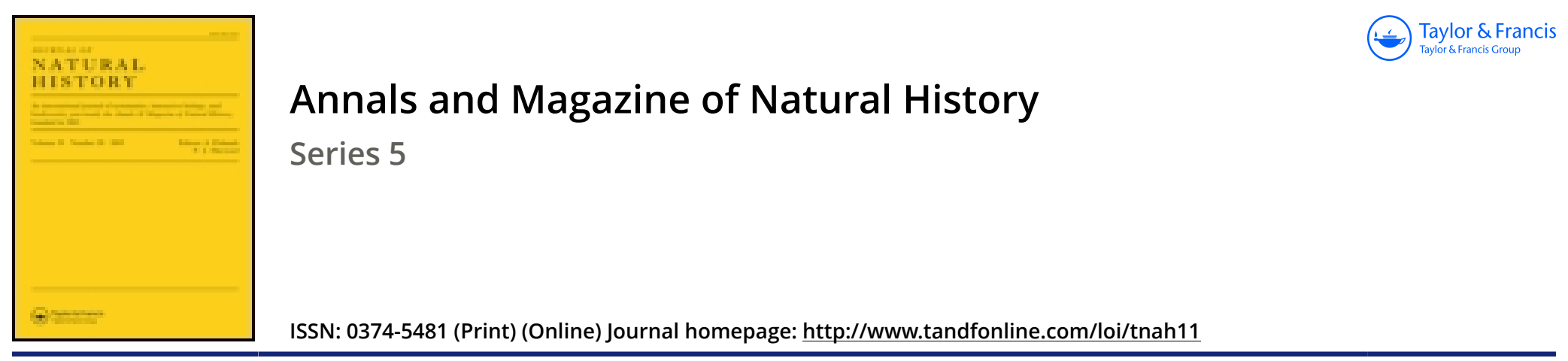

\title{
Note on Regalecus glesne, Ascanius
}

\section{James A. Grieg}

To cite this article: James A. Grieg (1887) Note on Regalecus glesne, Ascanius, Annals and Magazine of Natural History, 19:111, 246-247, DOI: 10.1080/00222938709460235

To link to this article: http://dx.doi.org/10.1080/00222938709460235

册Published online: 12 Oct 2009.

Submit your article to this journal

III Article views: 4

Q View related articles $₫$ 
Note on Regalecus glesne, Ascanius. By Jaxes A. Grieg.

This note relates to a herring-king found on the 9th March at Seimstranden, a little to the north of Bergen. It was in water about 2 metres deep, and was landed with some diffeulty, in consequenee of which, and of the lapse of a week before it was brought to the Museum at Bergen, it had sustained considerable injury. Since 1740, when the first herring-king was found on the Norwegian coast, this makes the fourteenth specimen known with certainty, so that on the average one of these animals has been stranded every ten years. On the English coast these fish oceur more frequently ; since 1759 twenty individuals have been stranded, or about one in every six or seven years.

The measurements of the Regalecus found at Seimstranden are as follows:-

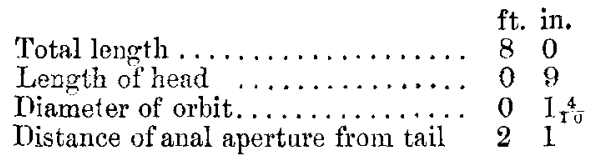

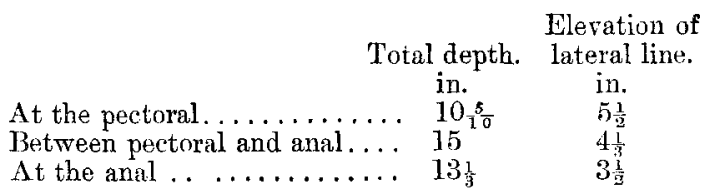

This Regalecus is the smallest known specimen, for it is barelv 8 feet long, and therefore a little smaller than the individual strander in Cornwall in 1788 ( $8 \frac{1}{3}$ feet, Day). Shaw's Gymnetrus Russellii, found at Vizagapatam in 1788, measured only $2 \mathrm{ft.} 8 \mathrm{in.}$; but it is uncertain whether this is identical with the northern Regalecus glesne. The Bergen Regalecus is also remarkable for its great depth, 15 inches, which is about one seventh of the total length, while the proportion varies in other cases between $\frac{1}{9}$ and $\frac{1}{1 \frac{1}{3}}$, and even sometimes falls to $\frac{1}{15}$; in the Comish specimen the proportion was $\frac{1}{10}$.

The pectorals had 12 rays. The number of occipital rays seems to have been 13 . The dorsal, which was of a fine red colour in the fresh animal, had 138 rays $(125+13)$; but the oxistence of a gap behind the occipital rays leads the author to conclude that there were altogether about 145 rays, probably more, as there were many rays broken and removed. If Lütken's supposition, that the number of dorsal rays increases with the age of the animal, be correct, as there is every reason to believe, the small number of rays in this specimen is very natural. Uufortunately the number of rays in the English Regaleus of 1788 is not stated; it would have been very interesting to compare the numbers in these two specimens of nearly equal size. The ventrals were represented by fragments $2 \frac{3}{4}$ and $1 \frac{\mathrm{l}}{6}$ in. long. 
The end of the tail, as usual in the Regaleci, is obliquely truncated; at the extreme tip there was a small scar or mark.

The length of the head, 9 inches, is contained $11 \cdot 7$ times in the total length, so that it is larger in proportion than usual; according to Lütken the proportion varies between $\frac{1}{16}$ and $\frac{1}{21}$. The head showed the typical form of the genus, and, as in the two older and larger specimens in the Bergen Museum, there are no teeth. The apparatus of teeth, mentioned by Collett, on the first branchial arch seems to have about 40 rays, but the head is so much damaged. that it is impossible to state the exact numbor. The tongue also was lost. The pupil was round and deep black, and the iris silvery white in the fresh animal. The silvery-white body had several black cross bands, of which five larger ones extended across the whole side obliquely from above downwards.

This herring-king thereforo differs from the typieal Regalecus glesne only in its comparatively larger head, its greater depth, and the smaller number of rays in the dorsal ; but as these characters are very variable, the specimen may be regarded as a true Regalueus glesne.

The distance from the tip of the snout to the anus is about 6 feet, or 75 per cent. of the total length, and a proportion so abnormal that the author concludes that a portion of the tail had been lost, as according to Collett the normal proportion is $\frac{4}{10}$ instead of $\frac{3}{4}$. Hence this animal would normally have measured nearly $15 \frac{1}{2}$ feet in length, which is not unreasonable, as examples have been met with over 5 motres in length, and this supposition is confirmed by the great depth of the body. It must, however, be remarked that the caudal part was complete and smooth with the exception of the fresh lesion at the apex; the form of the tail most resembled that of the Stavanger specimen of 1881.

The individual was a female with a well-developed ovary. The upper part of the intestine was empty, while the lower part contained a yellowish-brown undeterminable fluid.-Nyt Magazin for Naturvidenskaberne, Bd. xxx. p. 232.

\section{Carterius Stepanowii, Petr. By H. J. Carter, F.R.S. \&c.}

This freshwater sponge, which in 1884 was named "Dosilia (?) Stepanowii" by Dr. W. Dybowski, from a specimen found near Charkow, in Southern Russia ('Annals,' 1884, vol. xiv. p. 60), was also found in 1885 by Prof. Fr. Petr, of the Cniversity of Prague, in the neightourhood of Deutschbrod, in Bohemia, about 60 miles south-east of that city ; and his description of it, which is beautifully illustrated, was published in the Czech language at Prague in 1886 ("Dodatky ku Fauně Ceských Hub Sladkovodnich," Tisdem dra. Ed. Grégra $\checkmark$ Praze, 1886). It appears to me to be the same as that discovered by Mr. H. Mills, of Buffalo, New York, in the Niagara River in 1880, viz. Carterius tubisperma (Proc. Acad. Nat. Sci. Philadelphia, 1 thb June, 1881, p. 150).

Thus this remarkable genus of Spongilla, first brought to notice 